\title{
MENTOROK A TANÁRKÉPZÉS RENDSZERÉBEN: VÉGZETTSÉG, JUTTATÁSOK
}

\author{
RÉVÉSZ JUDIT \\ a Tempus az Eötvös Loránd Tudományegyetem Bölcsészettudományi Karának \\ tanársegédje \\ balogrevesz@t-online.hu
}

2009 tavaszán a Tanárképzök Szövetségének támogatásával a szerzö kutatást végzett, amelynek célja az volt, hogy felmérje a magyarországi mentorok helyzetét, munkakörülményeit, a pedagógusképzö intézményekkel fenntartott munkakapcsolatuk jellegét, megismerje a véleményüket a munkájukról, a jelöltekröl, és a tanárképzésben bekövetkezö változásokról. A dolgozatban mentornak tekintettünk mindenkit, aki tanárjelölteket támogat a tanitási gyakorlatuk során. Ez a tanulmány egy hosszabb dolgozat azon része, amely a mentorok demográfiai jellemzőivel, képzettségükkel és juttatásaikkal valamint a munkakörülményeik javitására vonatkozó elképzeléseikkel foglalkozik.

\section{Bevezetés}

A felsőoktatásról szóló 2005. évi CXXXIX. törvény, majd az erre épülő 15/2006-os OM rendelet megváltoztatta Magyarországon a tanárképzést, többek között annak gyakorlati komponenseit is. A változás röviden úgy írható le, hogy az eddig megszokott, kb. 15 tanított órát tartalmazó, gyakorlóiskolában eltöltött tanítási gyakorlat mellett megjelenik egy teljes féléves, nem feltétlenül gyakorlóiskolában, hanem külső gyakorlóhelyen eltöltendő gyakorlati félév mentori ${ }^{1}$ támogatással. Bár napjainkban felerősödtek a viták a tanárképzés bolognai rendszerủ átalakításáról, a hoszszú, nem gyakorlóiskolában eltöltendő gyakorlati idő és a mentori támogatás változatlanul széles körü szakmai támogatást élvez (1. Csermely et al., 2010).

Az európai és észak-amerikai tanárképzési rendszerek közös jellemzöje, hogy az utóbbi évtizedekben megnőtt a képzési idő, a tanárképzés átalakulási folyamatában növekedett az iskolai gyakorlat aránya és jelentősége, erősödött az iskolák és az ott dolgozó kollégák szerepe a szakmai szocializációs folyamatban. A fent leírt tendenciáknak egyenes következménye, hogy a szakmai szocializációt az iskolákban támogató kollégák szerepe, kiválasztása, képzése, az őket körülvevő kommu-

\footnotetext{
${ }^{1}$ A tanulmányban mentornak nevezzük mindazokat a gyakorlatvezető tanárokat, akik tanárjelölteket támogatnak a tanítási gyakorlatuk folyamán, függetlenül attól, hogy gyakorlóiskolában vagy külső gyakorlóhelyen végzik a tevékenységüket.
} 
nikációs rendszerek a 80-as évektől a vizsgálódás előterébe kerültek (Warren Little, 1990; Hobson et al., 2008).

2009 tavaszán a Tanárképzők Szövetségének támogatásával a szerző kutatást végzett, amelynek célja az volt, hogy felmérje a magyarországi mentorok helyzetét, munkakörülményeit, a pedagógusképző intézményekkel fenntartott munkakapcsolatuk jellegét, megismerje véleményüket a munkájukról, a jelöltekről és a tanárképzésben bekövetkező változásokról. Ez a tanulmány egy hosszabb dolgozat azon része, amely a mentorok demográfiai jellemzőivel, képzettségükkel és juttatásaikkal foglalkozik. A következő kérdésekre keresi a választ:

- Milyen a férfiak és nők aránya a mentorok között?

- Milyen végzettséggel rendelkeznek a mentorok?

- Mit gondolnak a mentorok a mentorképzésről?

- Hogyan történik a mentorok kiválasztása?

- Milyenek a mentorok munkakörülményei, milyen juttatásokban részesülnek?

\section{A kutatásról}

Az adatgyüjtés 2008 tavaszán kezdődött. Nyolc interjú készült gyakorlóiskolai vezetőtanárokkal és külsőiskolai mentorokkal egyaránt. Az interjúalanyok között három férfi és öt nő volt, hárman gyakorlóiskolában, öten külső gyakorlóhelyen dolgoznak. Ketten magyarból, illetve angolból fogadnak tanárjelölteket, a többiek egy tantárgyból (biológiából, kémiából, matematikából és olaszból). Hárman végeztek mentori munkára felkészítő képzést, öten nem.

Az interjúk alapján a szerző kérdőívet ${ }^{2}$ állított össze és 2009 februárja és áprilisa között 245 kérdőívet gyüjtött be azoktól, akik tanárjelölteket támogatnak a tanítási gyakorlatukon és egyben a 10-19 éves korosztályt tanítják. A kérdőívet kitöltő mentorok 26 különböző pedagógusképző intézménynek dolgoznak és 40 különböző tantárgyat tanítanak. A válaszolók 42 százaléka dolgozik gyakorlóiskolában, 58 százaléka pedig külső gyakorlóhelyen. A mintában a férfiak és a nők aránya 20,5 és 79,5 százalék. Az átlagos életkor 47 év. A mentorok által fogadott jelöltek száma félévenként átlagosan 4,2, a leggyakoribb érték 2 (18\%).

A kutatás célja az állapotfeltárás, az általunk vizsgált szakmai csoport jobb megismerése volt. Általánosságban azt feltételeztük, hogy itt is, mint az oktatás bármely más metszetében visszaköszön a tanári szakma félprofesszionális jellege, az általánosan elfogadott standardizált eljárások hiánya, a juttatások szükössége. A kérdőív eredményeinek feldolgozásánál az SPSS statisztikai programot használtuk, kereszttáblákat, a kétmintás t-próbát és a Spearman összefüggés-vizsgálatot.

\footnotetext{
${ }^{2}$ A teljes kérdőív elektronikus változata megtekinthető a következő címen: http://mentor.amorf.net/ public/
} 


\section{A kutatás szóhasználata}

Mind a jogi szabályozásban, mind a szakmai szóhasználatban fellelhető egyfajta terminológiai bizonytalanság: mentorokról, szakvezetőkröl, tereptanárokról (Péchy, 2004), vezetőtanárokról, valamint gyakorlóiskolákról, külső gyakorlóhelyekről, bázisiskolákról beszélünk, sokszor nehezen követhető módon.

Vezetőtanárnak a törvény azt nevezi, aki a tanárjelöltek gyakorlati képzésének a feladatát is ellátja, általában gyakorlóiskolában dolgozik vezetőtanári kinevezéssel. Az iskola fenntartója, gyakorlóiskola esetén, a képzőintézmény, ritkábban a helyi önkormányzat. Munkakörülményeit a közoktatási törvény szabályozza, kötelezö óraszáma meglehetősen alacsony, az átlagos óraszám fele. Ezt kiegészítheti egy vezetőtanári pótlék, aminek az összege általában elég jelentéktelen, havi pár ezer forint.

Bár bizonyos képzési helyszíneken mindig is dolgoztak külsőiskolai mentorok, ők a felsőoktatás expanziójával párhuzamosan még nagyobb számban jelentek meg. Ezek a kollégák egy más konstrukcióban végzik ugyanazt a feladatot. Ritkán előfordul, hogy órakedvezményt kapnak, ez az önkormányzat nagyvonalúságán múlik. Általában azonban a képzőintézménnyel közvetlenül szerződnek, és a mentori feladatok ellátásáért pénzt kapnak. A helyzetet tovább bonyolítja, hogy a gyakorlóiskolákban is végeznek mentori tevékenységet olyan kollégák, akiknek nincs vezetőtanári kinevezésük. A mi mintánkban a gyakorlóiskolai kollégák közül 15 százalékának 22 óra vagy magasabb a heti kötelező óraszáma.

Vizsgálatunkban gyakorlóiskolai és külsőiskolai mentorokkal foglalkozunk. Külsőiskolai mentornak tekintünk mindenkit, aki nem gyakorlóiskolában végzi a tevékenységét. Mint fentebb említettük, a válaszolók 42 százaléka dolgozik gyakorlóiskolában, 58 százaléka pedig külső gyakorlóhelyen. Országos adatok nem állnak rendelkezésünkre, jelenleg nem létezik a mentorokról országos nyilvántartás, bár létrehozása szerepel a javaslatok között (Bácsi et al., 2009). A velünk együttmüködő pedagógusképző intézményektől sikerült adatokat beszerezni (lásd 1. táblázat).

1. táblázat: A gyakorlóiskolai és külsőiskolai mentorok száma és aránya

\begin{tabular}{|l|c|c|}
\hline \multirow{2}{*}{} & \multicolumn{2}{|c|}{ Mentorok száma } \\
\cline { 2 - 3 } & Gyakorlóiskola & Külsö gyakorlóhely \\
\hline Eötvös Loránd Tudományegyetem & $142(26 \%)$ & $330(74 \%)$ \\
\hline Nyugat-Magyarországi Egyetem & $65(72 \%)$ & $25(28 \%)$ \\
\hline Pázmány Péter Katolikus Egyetem & $23(18 \%)$ & $103(82 \%)$ \\
\hline Pécsi Tudományegyetem & $45(57 \%)$ & $33(43 \%)$ \\
\hline Pannon Egyetem & 0 & $87(100 \%)$ \\
\hline Budapesti Müszaki Föiskola & $6(34 \%)$ & $12(66 \%)$ \\
\hline Corvinus Egyetem & $10(39 \%)$ & $16(61 \%)$ \\
\hline Budapesti Gazdasági Föiskola & 0 & $16(100 \%)$ \\
\hline
\end{tabular}


A fenti arányok rendkívül változatos képet mutatnak, mindenesetre valószínűsíthető, hogy a külsőiskolai mentor a gyakorlóiskolai vezetőtanár mellett általánosan elterjedt szereplöje a tanárképzésnek. Vizsgálatunkban igyekszünk ezt a két alcsoportot összehasonlítani, hiszen az új tanárképzési elképzelésekben mindkét csoport szerepet kap, és várható, hogy növekszik a külsőiskolai kollégák szerepe. Mindkét csoportot mentornak nevezzük, két okból. 1. A tevékenységük azonos jellegü, a szükséges tudás és készségelemek azonosak. 2. Szakma-szociológiai szempontból pozíciójuk oktatási középvezető jellegü (vagy az lehetne).

\section{A vizsgálat eredményei}

\section{A nö és a férfi arány}

A munkaszociológia világában köztudomású, hogy a nemek szerinti megoszlás összefügg a pálya presztízsével, a szakma munkaerőpiacon elfoglalt helyzetével, az elérhető jövedelmekkel: a nők aránya negatívan korrelál a fenti a mutatókkal. A tanári professzióval foglalkozó irodalom is nagy hangsúlyt fektet a női munkavállalók sajátosságaira, és szoros összefüggést lát a női munkavállalók magas aránya és a tanári szakma félprofesszionális jellege között (Simpson és Simpson, 1969; Lortie, 1975; Freidson, 2001). A férfi munkavállalók nagy száma pozitívan korrelál az elfoglalt pozíció presztízsértékével és díjazásával.

Azt feltételeztük, hogy a mintánkban a nő és a férfi arány tükrözni fogja az ezt a korosztályt tanítók általános férfi és nő arányát $(29 \text {, illetve } 71 \%)^{3}$, azaz a férfiak aránya nem lesz jelentősen magasabb, mint országosan. Azt feltételeztük, hogy a mentorságot nem tekintik igazán karriernek a kollégák a juttatások alacsony szintje és hierarchiában elfoglalt definiálatlan helyzete miatt. Ez szemben áll például a közoktatási vezetők (iskolaigazgatók, igazgatóhelyettesek) nemek szerinti megoszlásával, ahol a férfiak aránya magasabb, mint az oktatási intézményekben általában. A középiskolákban a vezetők 48 százaléka férfi, 52 százaléka nő. A mi mintánkba is bekerültek oktatási vezetők (23 fö), az ő nemek szerinti megoszlásuk körülbelül megfelel az országos aránynak, 45 százalékuk férfi és 55 százalékuk nő.

A mi teljes mintánkban a férfiak és a nők aránya: 20,5 és 79,5 százalék. Ahogy fent jeleztük, a 10-19 éveseket tanítók körében országosan ez az arány 29, illetve 71 százalék. Ez az adat némileg meglepő, inkább az ellenkezö irányban vártunk kismértékü eltérést.

Megnéztük a nemek arányát a gyakorlóiskolák és külső gyakorlóhelyek vonatkozásában. Azt gondoltuk, hogy a gyakorlóiskola több szempontból is vonzó munkahely a szakmán belül, a csökkentett kötelező óraszám, a jó hírnév, a képzőintézmény szakmai közelsége és az ebből adódó többlet lehetőségek miatt. Az OKM

\footnotetext{
${ }^{3}$ Az országos adatok az OKM Statisztikai Osztályától, név szerint Könyvesi Tibortól származnak.
} 
közlése szerint a gyakorló középiskolákban tanítók között (vezetőtanárok és nem vezetôtanárok együttesen) a férfi és a nő arány országosan a következőképpen alakult 2008/2009-es tanévben, fő munkaviszonyú pedagógusok esetében: gimnáziumokban 71 százalék nő, szakközépiskolákban 67 százalék. Ha csak a felsőoktatási intézmények gyakorlóiskoláit vesszük figyelembe, akkor az arány a gimnáziumokban 68 százalék nö, szakközépiskolákban 62 százalék. A válaszadóinkból kiindulva, a mentorok között ebben a bontásban is több a nő, mint azt a populáció összetétele alapján várnánk. A gyakorlóiskolákban valamivel több férfi mentor töltötte ki a kérdő́vet (23\%), mint a külső gyakorlóhelyeken (18\%), ez azonban még mindig alacsonyabb, mint az országos arány (29\%).

Összefoglalva: a nemek aránya alapján feltételezhetjük, hogy a mentorságot nem tekintik a kollégák karriernek, sőt, a válaszadók közül még kevesebb férfit vonzott, mint várható lett volna az országos adatok fényében.

\section{A mentorok végzettsége}

Köztudomású, hogy a hagyományos professziók esetében, mint például az orvoslás, a szakmán belüli speciális tevékenységek újabb képzettséghez, általában szakvizsgához kötöttek, de igaz ez a pszichológus szakmára is, pedig fiatalabb hivatás, mint a tanárság. A szakvizsgára előkészítő képzés megkezdése általában szakmai gyakorlathoz kötött, jogászok esetében ez például három év.

Vizsgálatunkat 2009 tavaszán végeztük. A 277/1997. (XII. 22.) számú Kormányrendelet szerint ,„5) 2010. január 1-jétől kezdődően közoktatási intézmény vezetésére, 2015. január 1-jétől kezdődően pedig vezető tanári (gyakorlatvezetö, óvónői, tanítói) feladat ellátására új megbízást az kaphat, aki rendelkezik pedagógus-szakvizsgával." Ugyanez a rendelet a szakvizsga mellett a tudományos fokozatot is elfogadja és a 13. paragrafusban három év szakmai gyakorlatot ír elő a szakvizsgára előkészítő képzés megkezdéséhez. Míg az iskolaigazgatók esetében újbóli kinevezés esetére közoktatási vezetöi képesítést követel meg, a mentorok számára a szakvizsgára előkészítő képzés tartalmára vonatkozóan nem rendelkezik. A 41/1999-es miniszteri rendelet a szakvizsgára előkészítő képzésekről szólván a szabadon választható tanulmányi területek között a következőket jelölte meg: mérési és értékelési, szaktanácsadói, vizsgaelnöki vagy szakértői feladatok, illetve a Ktv. 95/A. §-a (2) bekezdése szerinti minőségbiztosítási feladatok ellátására is folyhat felkészítés. Ezek között tehát a vezetőtanári feladatokra való felkészítés nem szerepelt.

2004-ben létesült egy gyakorlatvezető tanári szakirányú továbbképzés, ami azonban mindössze két évig élt, mert a 2005-ös felsőoktatási törvény törölte az összes szakirányú továbbképzési szakról szóló rendeletet, azóta intézményi hatáskörben adható ki ilyen speciális szakképzettséget igazoló oklevél. 2006-ban azután a 10/2006-os OKM rendelet 2. számú mellékletében ,a tanári mesterszak szakmai 
gyakorlatának vezetéséhez szükséges gyakorlatvezető mentori ismereteket" is felsorolta a szakvizsgára előkészítő képzések választható ismeretkörei között (Soósné, 2009).

Amint a fentiekből is látható, a jogi szabályozás viszonylag új keletủ és bizonytalanságokat mutat: szakadékot találunk a törvényben elöírt szükséges képesítés és a mentori feladat sajátosságai között (F. Péchy, 2004). Külön vizsgáltuk tehát, hogy a mentorok milyen arányban rendelkeztek a törvényben elöírt végzettséggel (bármilyen szakvizsga vagy doktori fokozat), és milyen arányban végeztek kifejezetten a mentori feladatokra felkészítő képzést (vezetőtanári szakvizsga vagy mentorképző tanfolyam). Azt találtuk, hogy tízen rendelkeznek doktori fokozattal $(4,2 \%)$, 86 fó (36\%) rendelkezett szakvizsgával (15,4\% vezetőtanári szakvizsgával, 20,4\% egyéb szakvizsgával). Voltak olyan mentorok, akik doktori fokozatot és szakvizsgát is szereztek, tehát 2009 tavaszán a válaszoló mentoroknak mindössze 38,3 százaléka rendelkezett a törvényben elöirt képesitéssel.

A válaszoló mentorok 34 százaléka (83 fö) végzett kifejezetten a mentori feladatokra felkészítő képzést akár szakvizsgás, akár tanfolyami keretben. Ha megnézzük ezt az adatot a vizsgálaton belüli alcsoportok szempontjából, azt találjuk, hogy külső gyakorlóhely vagy gyakorlóiskola szempontjából nincs különbség a mentorképzés elvégzésében. Jelentős eltérést az angol és német nyelvtanárok és a többiek között találunk $(\mathrm{p}=0,000)$. A mentorképzést végzettek 74 százaléka közülük kerül ki, míg a mintán belüli arányuk 39 százalék. Ök magyarázzák a humán tárgyakat tanítók előnyét is. Ha őket kivesszük az elemzésből, a szignifikáns összefüggés megszünik $(\mathrm{p}=0,568)$. A jelenség magyarázata, hogy a 90 -es évek elején nemzetközi együttmüködések keretében országszerte beindultak az angol és német hároméves tanárképző programok. Ezek a programok kivételes anyagi lehetőségekkel bírtak, sokszor szorosan együttmüködtek a célnyelvi ország szakembereivel, így olyan fejlesztési lehetőségeket valósíthattak meg, amelyek akkoriban gyakran még a célnyelvi országokban sem voltak általánosan elterjedtek. Az egyik ilyen fejlesztés maga a mentorképzés volt, amelynek kurzusai azután egymás után indultak be az ELTE-n, Nyíregyházán, Veszprémben, Szegeden és a hároméves programok egyéb helyszínein.

\section{Mentorképzések}

Mint az imént említettük, 83 fö végzett mentori feladatokra felkészítő képzést, akár szakvizsgás, akár tanfolyami keretben. A mentorképzések időtartama rendkívüli változatosságot mutat: a legrövidebb 15 órás, a leghosszabb 400 órás. Ez utóbbiban benne foglaltatik az egész szakvizsgára előkészítő képzés, aminek csak egy része foglalkozott a mentori munka sajátos feladataival. A mentorképzés átlagos hossza 150 óra, a leggyakoribb hosszúság 120 óra (45\%). A rendkívül nagy szórás arra utal, hogy nincs megegyezés arra vonatkozóan, hogy egy mentornak milyen jellegü szakmai felkészülésre van szüksége. 
A mentorképzést végzettek általában elégedettek voltak a képzéssel, ötfokú skálán átlagosan 4,53-ra értékelték. Az általuk adott minősítés és a szöveges indoklás megmutatja, hogy mi fontos a mentorok számára egy ilyen képzésben. 59 fó osztotta meg a képzéssel kapcsolatos gondolatait. A válaszaikból kiderült, hogy nagyra értékelték, ha a képzés gyakorlatias volt és nehezményezték, ha sok volt a számukra használhatatlan elméleti ismeret.

Az egyik elégedetlen mentor (kettest adott a képzésére) így fogalmazott: „Az előadások túl elméletiek voltak, semmi kézzelfogható segítséget nem kaptunk." Egy másik szerint, aki közepesre értékelte a képzését, „,sok felesleges és nem felhasználható információ halmazt kellett bemagolni." A következő két idézet olyanoktól származik, akik négyesre értékelték a képzésüket: „Több órát szerettem volna kapni szakmódszertanból.” „A képzés gyakorlati részét nagyon hasznosnak találtam. Az elméleti részben sok olyan anyagot dolgoztunk fel, amely a mindennapi munkában használhatatlan." Akik elégedettek voltak, azok a képzésük erényeit a tanfolyamok hasznosságában, gyakorlatiasságában látták. Nagyra értékelték a kapcsolatot a többi résztvevővel, a képzőintézménnyel és a trénerekkel, akiket mintaként neveztek meg. A képzés leggyakrabban említett hozadéka a képzőintézmény jelöltekkel szembeni elvárásainak megismerése és a szakmai standardok harmonizálása volt: „Megismerhettük, mit tanítanak és mit várnak el a hallgatóktól, így teljesen világos lett mindannyiunk számára, hogy milyen elméletet kell gyakorlatban megmutatnunk." A 83 mentorképzést végzett mentor közül 92 százalék (76 fö) a képzőintézmény szervezésében végezte a tanfolyamot, ami örvendetes arány. Az a tény, hogy tanár-továbbképzéseket képzőintézményeken kívül is meghirdetnek még önmagában nem mond semmit a képzések színvonaláról, azonban ezek a képzések nem tölthetik be azt a híd funkciót, amit a mentorok a képzésektől várnak.

Akik elégedettek voltak a képzésükkel, azok úgy érezték, hogy alapos visszajelzést kaptak. Sokan említették még a módszertani fejlődést és néhányan a személyiségfejlődést, mint a képzés pozitív következményeit.

A mentorképzés szükségességéről már a képzéssel kapcsolatos véleményekben is kaptunk információt. Az egyik, mentorképzést végzett kolléga így írt: „Teljesen új színben látom a vezetőtanár feladatát, sok gyakorlati fogást elsajátítottam és tanárként is rengeteget tanultam. A mentorkurzus épp annyira fontos a vezetőtanár számára, mint a pedagógiai, pszichológiai képzés a tanároknak.” Azt is meg akartuk tudni, hogy azok, akik nem végeztek mentorképzést, mit gondolnak ennek szükségességéről. A 23. kérdés így hangzott: „Ha nem végzett célzottan a mentori munkára előkészítő tanfolyamot, Ön szerint szükséges-e egy ilyen képzés?” Azért idézzük szó szerint, mert meglepő módon olyanok is véleményt nyilvánítottak ennél a kérdésnél, akik végeztek tanfolyamot. Mind a 27 fő igennel válaszolt, azaz szükségesnek ítélte a mentori munkára felkészítő képzést. A kérdésre összesen 161 fő válaszolt. Ha csak azoknak a válaszait vesszük alapul, akiket kérdeztünk, 
akkor 134 érvényes válaszunk marad. Közülük 94 fő válaszolt igennel (70\%). A mentorképzés szükségességének megítélése nem függött attól, hogy a mentor gyakorlóiskolában vagy külső gyakorlóhelyen dolgozik. A férfiak közül valamivel többen támogatták a képzés gondolatát, mint a nők közül $(\mathrm{p}=0,041)$, de sem a tanítási tapasztalattal, sem a mentori tapasztalattal nem függött össze a mentorképzés szükségességének megítélése.

Azok között, akik szükségesnek ítélték a mentorképzést, a leggyakrabban említett indoklás a tanárképzés megismerése és az elvárások egységesítése (28 fö a 121ből) volt. Említették még, hogy bepillantást nyerhetnek a képzőintézményben folyó képzésbe. Ez annál is fontosabb, mert a mintánkban szereplő mentorok 41 százaléka nem tudta, hogy a tanítási gyakorlatra általuk adott osztályzat része-e az államvizsga végső minősítésének. Elképzelésük szerint a mentorképzés folyamán tanulhatnának más mentorok tapasztalatából, növekedne a szakmai biztonságérzetük, szervezési és adminisztrációs segítséget kaphatnának. Említették még a szakmai megújulást, a tudatosabb feladatvégzést, a szakmai eszköztár gazdagodását. Szerintük a mentori munka más jellegü tevékenység, mint a középiskolai tanítás.

Akik szerint nem szükséges a mentorképzés (40 fö, 30\%), azok úgy gondolják, hogy a saját szakmai közegükben elegendő támogatást kapnak, a képzőintézménynyel fenntartott kapcsolatuk elég intenzív, eredeti képzettségüket és tapasztalatukat elegendőnek érzik, és attól tartanak, hogy a képzés túl elméleti lenne. Néhányan megemlítették még, hogy az iskola mindennapjaiba szocializálják a jelölteket.

\section{A mentorok kiválasztása}

Egy, az Amerikai Egyesült Államokban végzett vizsgálat szerint a mentorprogramok hatékonyságának megítélését alapvetően meghatározta, hogy a programok résztvevői mennyire tekintették hitelesnek a mentorok kiválasztásának folyamatát. (Warren Little, 1990). A legsikeresebb kaliforniai programban a szelekció során a képzőintézmény képviselőinek adatforrásai a következők voltak:

- az iskolaigazgatók véleménye,

- a tanár munkáját értékelő dokumentumok,

- interjú,

- óralátogatások.

A folyamat végén a jelentkezők egyharmadát találták alkalmasnak.

A kiválasztási folyamatban annál is inkább elvárnánk a képzőintézmény részvételét, mert a mentorok a maguk sajátos módján a képzőintézmény munkatársaivá válnak. A mi mintánkban mindössze a válaszolók 40 százalékát látogatták meg a képzőintézménytől, mielőtt felkérték a mentori feladatok ellátására. 34 százalék esetében sem az iskolavezetés, sem a képzőintézmény nem végzett óralátogatást. 14 százalék (34 fö) személyes ismeretség alapján lett mentor. Közülük 18 fó esetében (53\%) nem előzte meg a kiválasztást óralátogatás, elég volt a személyes kapcsolat. 
A mi mintánkban 11 százalék (26 fö) azoknak az aránya, akik maguk keresték a mentori munka lehetőségét. Közülük tíz fő esetében nem előzte meg óralátogatás a mentori tevékenység megkezdését.

A mentorok szakmai szocializációs ágensek, ezért esetükben különös jelentőséggel bír a szakmai tapasztalat. A szükséges tapasztalat meghatározására többféle referenciát is találhatunk. Berliner (2005) egy amerikai vizsgálatban például azt találta, hogy a tanárok diákjaik eredményei alapján hét év után érik el a csúcsformájukat. Magyarországon általában a mentorképzések felvételi követelménye öt év szakmai tapasztalat (például PTE, ELTE, ATAK). A mi vizsgálatunkban is megkérdeztük a mentorokat, hogy hány év szakmai tapasztalattal rendelkeztek, amikor megkezdték mentori tevékenységüket. Az átlagos érték 11, a legtöbb 36, a legkevesebb 0 év szakmai tapasztalat volt (1 fö). Összesen 10 százalékuk kevesebb, mint öt év tapasztalattal rendelkezett. A szakmailag tapasztalatlan kollégák beengedése a mentorok közé újabb jele a kiválasztás bizonytalanságának, a tevékenység meghatározatlan státuszának, amit az óralátogatások fent leírt esetlegessége is alátámaszt.

\section{A mentorok juttatásai: pénzbeli juttatások}

A juttatásokkal kapcsolatos kérdést egyfajta szemérmesség övezte. Míg 230 fö válaszolt arra, hogy részesül-e juttatásban, a juttatás mértékét firtató kérdésekre csak 179 fö adott választ. A 100 gyakorlóiskolai kolléga közül 14 számolt be pénzbeli juttatásról (átlag $38209 \mathrm{Ft}$ ), 74 heti órakedvezményről. A külsőiskolai kollégák közül 64-en nyilatkoztak a pénzbeli juttatásaikról, ez átlag $41434 \mathrm{Ft}$, és mindössze öten jeleztek órakedvezményt.

A válaszoló mentorok félévenként átlagosan 41730 Ft nettó jövedelemröl számoltak be, a középérték $30000 \mathrm{Ft}$. A félévenként fogadott jelöltek száma átlagosan 4,2 , de ez az adat magában foglalja a bizonyos helyeken szokásos csoportos gyakorlatot is. A leggyakoribb fogadott jelöltszám félévenként kettő. A fent említett $41434 \mathrm{Ft}$ nettó jövedelem tehát jelöltenként körülbelül $20000 \mathrm{Ft}$ nettó jövedelmet takar. Ez egy teljes tanévre számítva $80000 \mathrm{Ft}$ körüli nettó jövedelmet jelent.

Megkíséreltük ezt az adatot nemzetközi összefüggésben vizsgálni. Az Eurydice dokumentumaiban nem találtunk a mentorok jövedelmére vonatkozó adatokat. Warren Little (1990) az Amerikai Egyesült Államok mentorprogramjairól szóló írásában évi 4000 dolláros mentori juttatást említ, ami az ottani tanári éves átlagkeresetnek körülbelül 10 százaléka. A mi válaszolóink esetében a mentori munkáért kapott juttatás mindössze az éves jövedelem 3-4 százaléka. Az amerikai példában a mentorprogram költségvetésének kétharmad része közvetlenül a mentorokhoz került.

\section{A mentorok juttatásai: órakedvezmény}

Mintánkban az átlagos kötelező heti óraszám 17,5. Ebben benne foglaltatik az a 23 fö is, aki iskolai vezetőként kap jelentős órakedvezményt. Az átlagos ténylegesen ta- 
nított heti óraszám 20,7. A leggyakoribb értékek 21 és 22. Összesen 86 fö kap órakedvezményt a mentori tevékenységgel összefüggésben. A gyakorlóiskolák esetében ez 81 fö 93-ból, míg öt külsőiskolai kolléga kap órakedvezményt a 135-ből. A gyakorlóiskolák esetében a mentorok kötelező heti óraszáma átlagosan 5,25 órával kevesebb, mint a külső gyakorlóhelyeken. Külső iskolákban dolgozó mentorok közül egyvalaki heti egy órát kap, két fő heti két órát és egy fő heti öt órát. Az ötödik válaszoló nem nyilatkozott az órakedvezmény mértékéről.

Összehasonlítottuk a heti kötelező és ténylegesen tanított órák számát (2. táblázat). Ezek az adatok ritkán esnek egybe, már csak az iskolai órarendkészítés nehézségei miatt is.

2. táblázat: A kötelező és a ténylegesen tanított óraszám

\begin{tabular}{|l|l|r|c|c|c|}
\hline & & $N$ & Átlag & $\begin{array}{c}\text { Std. } \\
\text { deviation }\end{array}$ & $\begin{array}{c}\text { Std. error } \\
\text { mean }\end{array}$ \\
\hline \multirow{2}{*}{ Tanított óraszám } & Gyakorlóiskola & 99 & $\mathbf{1 9 , 1 2}$ & 7,639 &, 768 \\
\cline { 2 - 6 } & Külső gyakorlóhely & 134 & $\mathbf{2 1 , 9 2}$ & 6,497 &, 561 \\
\hline \multirow{2}{*}{ Kötelezö óraszám } & Gyakorlóiskola & 98 & $\mathbf{1 4 , 4 6}$ & 5,032 &, 508 \\
\cline { 2 - 6 } & Külső gyakorlóhely & 136 & $\mathbf{1 9 , 7 1}$ & 6,114 &, 524 \\
\hline
\end{tabular}

Mint a 2. táblázatból is látható, a kötelező óraszámok közötti átlagos 5,25 óra különbség, a két iskolatípus között, a ténylegesen tanított órák esetében, a felére csökken (2,8 óra). Mentoraink átlagosan 20,7 heti tanított óra mellett látják el a jelöltekkel kapcsolatos feladataikat, ami az egyik válaszoló szerint körülbelül heti öt óra elfoglaltságot jelent. Feltételezhetjük tehát, hogy a mentorok időszükében érzik magukat.

Arra is kíváncsiak voltunk, hogy az órakedvezmény hogyan hasznosul a mentorok szakmai életében. Feltételeztük, hogy a gyakorlóiskolai kollégák közül többen vesznek részt továbbképzéseken, konferenciákon, és többet publikálnak, mint a külső iskolai kollégák. Megvizsgáltuk, hogy a mentorok milyen arányban szereztek magasabb szintủ végzettséget (a szakvizsgát vagy a doktori fokozatot értettük ez alatt). Azt találtuk, hogy a gyakorlóiskolai kollégák közül 41 százalék, míg a külsőiskolai kollégák közül 35 százalék szerzett ilyen jellegü újabb diplomát. A mentorképzést végzettek aránya is hasonló: a gyakorlóiskolában dolgozó mentorok 37 százaléka, a külső iskolában dolgozó mentorok 33 százaléka végzett mentori munkára felkészítő képzést, akár szakvizsgás akár tanfolyami keretben. Van tehát különbség a gyakorlóiskolai kollégák javára, de a különbség statisztikailag nem jelentős.

Azt is megkérdeztük, hogy az utóbbi öt évben milyen egyéb szakmai jellegü iskolán kívüli tevékenységeket végeztek a mentorok. Azt találtuk, hogy az összes válaszoló 92 százaléka vett részt továbbképzésen, 27 százalékuk oktatóként. 78 százalék vett részt szakmai konferenciákon, 29 százalék előadóként is szerepelt. A men- 
torok 30 százaléka publikált az elmúlt öt évben. Ezen adatok érdekessége, hogy egyik kategóriában sem találtunk szignifikáns különbséget a gyakorlóiskolában és a külső iskolákban dolgozó kollégák között.

A 46. kérdésben arra voltunk kíváncsiak, hogy a jelölt egy-egy megtartott órájára körülbelül hány percnyi közvetlen szóbeli jelölt-mentor kommunikáció esik. Bár feltételeztük, hogy az adatok némileg idealizáltak, azt gondoltuk, hogy ,a felfelé kerekítés" mértéke azonos a két általunk vizsgált csoportnál. Ebben a tekintetben a gyakorlóiskolában tanító mentorok és a külsőiskolai mentorok között lényeges különbség mutatkozott ( $\mathrm{p}=0,000)$. (Lásd 3. táblázat)

3. táblázat: Az egy megtartott órára eső közvetlen szóbeli jelölt-mentor kommunikáció percekben

\begin{tabular}{|l|l|c|c|c|c|}
\hline & & $N$ & Mean & $\begin{array}{c}\text { Std. } \\
\text { deviation }\end{array}$ & $\begin{array}{c}\text { Std. error } \\
\text { mean }\end{array}$ \\
\hline $\begin{array}{l}\text { Hány perc kommunikáció } \\
\text { esik a jelölt egy megtartott } \\
\text { órájára? }\end{array}$ & Gyakorlóiskola & 95 & $\mathbf{5 1 , 7 1}$ & 32,244 & 3,308 \\
\cline { 2 - 6 } & $\begin{array}{l}\text { Külső } \\
\text { gyakorlóhely }\end{array}$ & 133 & $\mathbf{3 7 , 0 6}$ & 20,873 & 1,810 \\
\hline
\end{tabular}

Egyértelmü összefüggést találtunk a kötelező óraszám (korrelációs együttható $=-0,184$, $\mathrm{p}=0,006$ ) és még inkább a ténylegesen tanított óraszám (korrelációs együttható= $-0,250, p=0,000)$ valamint a jelölttel folytatott szakmai beszélgetés hossza között. Általánosságban elmondhatjuk, hogy minél nagyobb az órakedvezmény, annál több figyelmet kap a jelölt szakmai tevékenysége.

\section{A mentorok a munkakörülményeik javitásáról}

Azt is vizsgáltuk, hogy a mentorok szerint milyen feltételekre és változtatásokra lenne szükség munkakörülményeik javításához. A szöveges válaszok egyértelmü tendenciákat mutatnak: a három legfontosabb téma az idő, a pénz és a szakmai kapcsolatok.

26 százalék említette a pénzbeli juttatás növelését. Egyik vélemény: „Jobb anyagi elismerés (mely lehetővé tenné, hogy a délutánok ne magántanítással, hanem mondjuk, szakmai elmélyüléssel teljenek).” Egy másik mentor szerint „megalázó az anyagi dotáció."

72 százalékuk említette az órakedvezményt. Egy példa: „Az órakedvezményre nagy szükség lenne, mert így sokszor egy-egy hallgatói óra után a saját órámra rohanok tovább, és nem is tudjuk rendesen megbeszélni a hallgató örömeit, gondjait, vagy békében készülni a következő órákra." Mint várható volt, a kétféle azonos munkát végző csoport közötti feszültség megjelenik a válaszokban, mint ahogy már az egyik interjúban is megjelent. „Mivel mentori munkámat heti 22 kötelező 
óra mellett végzem, túlzásnak tartom, hogy a kinevezett mentorok ugyanezért a munkáért kétszeresen is ,jutalmazva" vannak (állandó órakedvezmény és pótlék), miközben velem megbízási szerződést köt a képző intézmény."

14 százalék említette a kapcsolat javítását a képzőintézménnyel. Két vélemény: „Ingyenes szakmai továbbképzés (akár egy napos), más iskolákkal esetmegbeszélő napok biztosítása tapasztalatcsere céljából.” „Az egyetemi karok, szaktanárok együttmúködése a hallgatókkal (számukra is legyen órakedvezmény), több érdeklődés, figyelem az egyetem részéről."

Ha megnézzük a válaszokat az iskolatípusok szempontjából, azt találjuk, hogy bár a gyakorlóiskolai mentorok inkább több pénzt szeretnének, a különbség statisztikailag nem szignifikáns. Közülük is sokan megemlítik az órakedvezményt vagy a csökkentett kötelező óraszámot, mint ami megőrzendő vívmány, vagy mint ami mostanában veszélybe került vagy meg is szünt. A külső iskolai mentorok egyértelmüen órakedvezményt szeretnének $(\mathrm{p}=0,008)$.

A legtanulságosabb adat, hogy az összes válaszoló közül 84 fő (72\%) említi az órakedvezményt és csak 31 fó (26\%) a pénzt. Ezzel szemben áll, hogy a jelenlegi rendszerben a tanítási gyakorlathoz rendelt források a képzőintézménynél vannak és a képzőintézmény nincs abban a helyzetben, hogy az óraszámokat befolyásolja, különösen igaz ez a külső iskolák esetében, ahol a fenntartó legtöbbször az önkormányzat.

\section{Összefoglalás és kitekintés}

A mentor, mint a tanárképzés szereplöje, illetve a mentori tevékenység kevéssé intézményesült, ezt bizonyítja az azonos feladatot végzők munkakörülményei közötti jelentős különbség, a kiválasztás esetlegessége, a végzettség körüli bizonytalanság. Juttatások nem a feladathoz kötődnek, ellenkező esetben a külsőiskolai kollégáknak is jelentős órakedvezményt kellene kapniuk. A kollégák a mentorságot nagy valószínüséggel nem tekintik karriernek, szemben például a közoktatási vezetői feladatokkal.

$\mathrm{Az}$ új rendszerben számos előremutató kezdeményezés található. Szegeden előtakarékosságot terveznek, hogy az ötödik félévben elegendő pénz maradjon a mentorok díjazására. Az ELTE számításai szerint az egy hallgató féléves gyakorlatához rendelhetö összeg szakonként eléri a nettó $100000 \mathrm{Ft}^{-\mathrm{ot}^{4}}$, ami, ha mindkét félévben a mentorok jövedelmét gyarapítaná, akkor közel kerülhetnénk a kívánatosnak tartott évi 10 százalékos jövedelemnövekedéshez. Ez már jelentős vonzeröt jelenthetne a tanárok számára (vö. Bácsi et al., 2009). A féléves gyakorlaton kevéssé valószínü, hogy egy mentor egy jelöltnél többet fogadhatna. (Hacsak nem gondolkodunk el a párban tanítás alternatíváján, amire van magyarországi példa, és egyre többet

\footnotetext{
${ }^{4}$ Az ELTE Pedagogikum Központ, név szerint Salát Magdolna közlése 2010 júniusában.
} 
szerepel a nemzetközi szakirodalomban is (Barócsiné, 2008; Bullough et al., 2002). Sajnálatos még az a tény is, hogy ez a kiegészítő jövedelem jobbára csak az őszi félévben állhat a mentorok rendelkezésére. Feltételezhetjük, hogy ha ez az összeg átmegy az iskola szürőjén, akkor jelentős jövedelemnövekedésre nagy valószínüséggel nem lehet számítani.

Látnunk kell, hogy némileg meglepő módon, a mentorok számára a legfontosabb kérdés nem a pénz, hanem a mentori feladatokra fordítható idő. Az a tény, hogy a jelenlegi rendszerben a tanítási gyakorlat az őszi félévben összpontosul, megnehezíti az órakedvezmény kérdésének megoldását is. Az iskolák nem engedhetik meg maguknak, hogy a két félévben egy-egy tanárnak jelentősen eltérö számú órát adjanak.

Ami a mentorok végzettségét illeti, kívánatos lenne a végzettséget is a feladathoz és nem a feladatvégzés helyéhez igazítani. Érdemes lenne a mentorban az iskola életének egyik középvezetőjét látni (Poór, 2008), aki tapasztalata és végzettsége folytán egyaránt képes a tanárjelölteket és a kollégákat támogatni szakmai fejlődésükben (l. munkaközösség-vezetői feladatok, gyakornoki időszak alatt kezdő kollégák támogatása), és aki az új, vele azonos szakos kollégák felvételének is gazdája lehetne, aki segíthetné a tapasztalt, de új kollégák intézményi szocializációját is óralátogatásokkal, konzultációkkal. A tervezett képzéseket ennek fényében kellene kialakítani.

Mint láttuk, a mentorok döntő többsége egyetért a speciális felkészítés szükségességével, még azok is, akik jelenleg ilyen képesítés nélkül végzik a munkájukat. Az utóbbiak képzésekkel szembeni elvárásai egybeesnek a végzettek prioritásaival: gyakorlatias, a mentori tevékenységben jól használható képzést várnak, amely egyben lehetőséget biztosít a kommunikációra a kollégákkal, szakmai kapocsként szolgál a képzőintézmény és a mentorok között. Ez utóbbi igény mindenképpen a helyi mentorképzés mellett szól. Kívánatos, hogy a képzőintézmények maguk válasszák ki és képezzék a mentoraikat, a képzés engedjen bepillantást a képzőintézmény munkájába, szakmai elvárásaiba. Ez egyben tompíthatja azt a hatást, amiről a szakirodalomban oly sok szó esik, nevezetesen, hogy a képzőintézmény befolyása elolvad a későbbi munkahelyi szocializáció hatására. (Feiman-Nemser és Buchmann, 1985; Smagorinsky et al., 2003; Smagorinsky et al., 2004; Anagnostopoulos et al., 2007)

A mentor, különösen a külsőiskolai mentor, a szakmai szocializáció kulcsszereplöje, ő az, aki hitelesen képviseli a szakmát. Egyrészt a választása következtében: ő azt a munkát végzi, amire szocializál, míg a képzőintézmények oktatói egyértelmúen egy másik karriert választottak. Másrészt a mentorok rendelkeznek valamivel, amit az angol úgy hív, hogy „street validity”. Amit ők képviselnek, az kiállta az élet próbáját. A mentorság intézménye lehetne tehát az a stratégiai támadási pont, ahol a szakma elmozdulhatna a professzionalizálódás irányába. Ehhez kellene az egységes jogi, pénzügyi és emberi feltételeket megteremteni. 


\section{Irodalom}

Anagnostopoulos, D., Smith, E. R., Basmadjian, K. G. (2007): Bridging the universityschool divide: horizontal expertise and the "two-worlds pitfall". Journal of Teacher Education, 2. 138-153.

Bácsi János, Brezsnyászky László, Falus Iván, Iker János, Kotschy Beáta, Nagy Mária, Sándor József, Soósné Faragó Magdolna (2009): Javaslatok a tanárképzés utolsó, gyakorlati félévével kapcsolatos szakmai és gyakorlati kérdésekröl. Az OKM Közoktatási és Felsőoktatási Főosztálya, valamint az OFI által koordinált munkaanyag, Budapest, 2009. április 21 .

Barócsiné Kirilova, Sz. (2008): The Role of Co-operation in Pre-Service Teacher Education. Doktori értekezés, ELTE Neveléstudományi Doktori Iskola, Budapest.

Berliner, D. C. (2005): Szakértő tanárok viselkedésének leírása és teljesítményeik dokumentálása. Pedagógusképzés, 2. sz. 71-91.

Bullough, R. V., Young, J., Erickson, L., Birrell, J. R., Clark, D. C., Egan, M. W., Berrie, C. F., Hales, V., Smith, G. (2002): Rethinking Field Experience: Partnership Teaching versus Single-Placement Teaching. Journal of Teacher Education, 1. 68-80.

Csermely Péter, Fodor István, Joly, E., Lámfalussy Sándor (2009): Szárny és teher. http://bolcsektanacsa.solyomlaszlo.hu/letoltesek.htm

Etzioni, A. (1969): The Semi-Professions and their Organization. Free Press, New York.

F. Péchy Gabriella (2004): Gondolatok a mentori tevékenységről és a mentorképzésről. Egy mentor-nyelvtanár (ön)reflexiói. Magyar felsőoktatás, 5. sz.

Feiman-Nemser, S., Buchmann, M. (1985): Pitfalls of experience in teacher preparation. Teachers College Record, 1. 53-65.

Freidson, E. (2001): Professionalism: the third logic. University of Chicago Press, Chicago.

Hobson, A. J., Ashby, P., Malderez, A., Tomlinson, P. D. (2008): Mentoring beginning teachers: What we know and what we don't. Teaching and Teacher Education, 25. 207-216.

Lortie, D. C. (1975): Schoolteacher. Universtiy of Chicago Press. Chicago.

Poór Zoltán (2008): A mentori tevékenységhez szükséges kompetenciák és azok kialakitásának módszerei. Előadás Veszprémben az első Tanárképzés Napján, 2008. április. Kézirat.

Simpson, R. L., Simpson, I. H. (1969): Women and Bureaucracy in the Semi-Professions. In: Etzioni, A. (ed): The Semi-Professions and their Organization, Free Press, New York.

Smagorinsky, P., Cook, L. S., Jackson, A. Y. (2004): Tensions in learning to teach: Accommodation and the development of a teaching identity. Journal of Teacher Education, 55. 8-24.

Smagorinsky, P., Cook, L. S., Johnson, T. S. (2003): The twisting path of concept development in learning to teach. Teachers College Record, 105. 1399-1436.

Soósné Faragó Magdolna (2009): Háttértanulmány. In: Bácsi János - Brezsnyászky László - Falus Iván - Iker János - Kotschy Beáta - Nagy Mária - Sándor József - Soósné 
Faragó Magdolna (2009): Javaslatok a tanárképzés utolsó, gyakorlati félévével kapcsolatos szakmai és gyakorlati kérdésekről. Az OKM Közoktatási és Felsőoktatási Főosztálya, valamint az OFI által koordinált munkaanyag, Budapest. 2009. április 21.

Warren Little, J. (1990): The Mentor Phenomenon and the Social Organisation of Teaching. Review of Research in Education, Vol. 16. 297-351. 